\title{
INTEGRIDADE TERRITORIAL, AUTODETERMINAÇÃO, SECESSÃO E RECONHECIMENTO
}

\section{Francisco António de M. L. Ferreira de Almeida*}

SUmÁrio: 1. Integridade territorial. 2. Autodeterminação. 3. Secessão. 4. Reconhecimento.

RESUmo: Visa o presente artigo olhar às novas dimensões do princípio da autodeterminação dos povos, nas suas vertentes interna e externa, indagando, em especial, se, de entre aquelas, se conta um direito de secessão, que, a existir, mesmo que em casos-limite e a assumir uma feição de remédio, directamente põe em causa os fundamentos do princípio da integridade territorial dos Estados. No final, alude-se aos constrangimentos e limitações em termos de exercício de competências internacionais, caso não sobrevenha o reconhecimento pelos seus pares da entidade territorial recém-formada.

Palavras-chave: Estado; Povos; Minorias; Integridade territorial; Autodeterminação; Secessão; Reconhecimento.

Abstract: The present article seeks to look upon the new dimensions of the Principle of Peoples self-determination in its internal and external aspects, especially to question whether a Right of Secession might be drawn upon them, which, existing, directly compromises the fundaments of the Principle of Territorial Integrity of States, even in bordline cases and taking the form of remedy. At the end, its constrains and limitations are alluded to, in terms of exercise of international competences, should there be no recognition by the newly formed territorial entity's peers.

KeYwords: State; Peoples; Territorial integrity; Self-determination; Secession; Recognition.

\footnotetext{
* Professor da Faculdade de Direito de Coimbra e Professor Convidado da Faculdade de Direito da Universidade Lusófona (Lisboa).
} 


\section{INTEGRIDADE TERRITORIAL}

É pacífico na doutrina tratar-se o Estado de uma colectividade cuja existência repousa em três elementos constitutivos: a população, o território e o governo ${ }^{1}$. Acresce que beneficia de um atributo ou qualidade jurídica que o singulariza relativamente aos demais sujeitos de direito: a soberania ou independência.

$\mathrm{O}$ conceito de população carece de algumas explicações. $\mathrm{Na}$ verdade, sendo ela integrada pelo conjunto de indivíduos ligados a um Estado, de forma estável e duradoura, através do vínculo jurídico da nacionalidade (os seus nacionais), não deve, porém, ser confundida com as noções (mais sociológicas do que jurídicas) de povo ou nação. A estas últimas está subjacente uma ideia de homogeneidade. Quer dizer, os indivíduos que integram a nação ou o povo estão ligados por certas afinidades $-v \cdot g$., étnicas, rácicas, históricas, culturais, linguísticas, religiosas, etc. - , manifestando, em virtude disso, vontade de viverem em comum² ${ }^{2}$.

Ora, à luz do princípio das nacionalidades, surgido no séc. XIX, toda e qualquer nação ou povo teria o direito de constituir-se em Estado. Fomentando-se, pois, por seu intermédio, uma coincidência entre a realidade sociológica que é a nação (ou o povo) e a realidade jurídica que é o Estado, tenderia a haver tantos Estados quantas as nações. O Estado deveria ser, por conseguinte, um Estado-nacional e, caso englobasse várias nações, expor-se-ia ao desmembramento, rectius, aos fenómenos de secessão. A despeito de esse princípio das nacionalidades não haver logrado alcandorar-se ao patamar de princípio geral de direito internacional, dotado de validade universal, certo é que inspirou diversos regimes convencionais dos sécs. XIX e XX $(v \cdot g$., acordos de paz, reconhecimento colectivo de novos Estados, protecção de minorias, etc.) $)^{3}$. Não por acaso,

\footnotetext{
1 Cfr. JELLINEK, Allgemeine Staatslehre, $3^{a}$ edição, reimpressão, Bad Hamburg, 1960, pp. 136 e ss.; e 394 e ss.

2 Cfr., a propósito, QUOC DINH/DAILLIER/PELLET, Droit International Public, LGDJ, Paris, 1994, p. 401.

3 Ibidem, p. 401.
} 
de resto, a expressão "Direito Internacional", significa, em sentido etimológico, direito regulador das relações entre nações ou Estados ${ }^{4}$ - termos estes que, a certa altura, justamente em reverência àquele princípio, eram considerados sinónimos.

Semelhante entendimento não é, no entanto, coonestado pelo direito internacional moderno, visto que nenhuma regra do actual Direito das Gentes $^{5}$ postula a aludida correspondência entre Estado e nação. Pelo contrário, abundam na comunidade internacional os Estados que englobam várias nações $(v \cdot g$., alguns dos Estados europeus, A Rússia, a China, a maior parte dos Estados africanos, etc.), assim como, inversamente, se encontram nações dispersas ou disseminadas por vários Estados (os albaneses, os curdos, a diáspora judaica, antes da constituição do Estado de Israel, etc.).

Ainda assim, vislumbra-se no conspecto do direito internacional geral ou comum contemporâneo um princípio que, bem vistas as coisas, mais não representa do que uma refracção, conquanto parcial e mitigada, do princípio das nacionalidades do séc. XIX. Referimo-nos ao direito dos povos (ou naçôes) à autodeterminação. Direito esse que, todavia, na sua vertente externa, o direito positivo não reconhece senão a certas categorias de povos não autónomos, razão por que não exibe um carácter verdadeiramente universal (cfr., infra, $\left.\mathrm{n}^{\circ} 2\right)^{6}$. As considerações expendidas transportam-nos para os outros dois elementos constitutivos do Estado: o território e o governo. Do mesmo modo que a população, ambos se revelam imprescindíveis à existência de um Estado, tal como hoje o concebemos. E entre os três rutila uma forte interdependência. Vejamos.

A ligação umbilical entre Estado e território radica no direito internacional costumeiro. Não há Estado sem território, exígua que seja a dimensão deste.

4 Direito interestadual, portanto.

5 Expressão adoptada, no séc. XVI, por FRANCISCO VITORIA, um dos "pais fundadores do direito internacional", vindo depois a ser substituída pela designação "direito internacional" a partir do momento em que, com a paz de Westefália, se forjou uma sociedade estritamente interestadual. Sobre o assunto, veja-se Antônio CANÇADO TRINDADE, A Humanização do Direito Internacional, 2a edição, Del Rey Editora, Belo Horizonte, 2015, pp. 3 e ss..

6 Veja-se, neste sentido, o nosso Direito Internacional Público, 2a edição, Coimbra Editora, 2003, pp. 205-206. Nem de outra forma poderia ser, pois que uma visão racial do princípio das nacionalidades pretextou, ao longo da centúria pretérita, os maiores abusos e arbitrariedades, concretizados, designadamente, em políticas de extermínio de determinados grupos humanos (genocídio) ou na promoção de territórios "etnicamente puros" ("limpeza étnica"), com a consequente desintegração ou desagregação violenta de Estados multinacionais. 
Por outro lado, enquanto pessoa colectiva, o Estado necessita de órgãos que o representem e através dos quais possa exprimir a sua vontade. Pois bem, sendo a população estadual uma população sedentária, o poder político e administrativo do Estado é exercido sobre o respectivo território, em cujas fronteiras aquela se acha instalada ${ }^{7}$. Aí, as competências soberanas (territoriais e pessoais) do Estado são plenas e exclusivas, por contraste com aquelas outras que incidem sobre espaços submetidos, tão-somente, à sua jurisdição, caso, v. g., de algumas zonas marítimas como, por ex., a Zona Contígua, a Zona Económica Exclusiva ou a Plataforma Continental ${ }^{8}$. Destarte, mais do que um sujeito (teoria organicista do Estado), um objecto ou um limite do poder do Estado, o território constitui, isso sim, um verdadeiro título jurídico essencial das competências estaduais ${ }^{9}$. A sua dimensão hipoteticamente escassa não obsta, como se disse, à existência do Estado, para a qual um mínimo de base territorial se erige em condição necessária, mas também suficiente ${ }^{10}$.

Daqui decorre o princípio da integridade territorial (isto é, da tendencial indivisibilidade ou estabilidade do território), consagrado em inúmeros documentos e instrumentos normativos internacionais, de que se destacam a Carta das Nações Unidas, bem como as cartas constitutivas da Organização dos Estados Americanos e da União Africana. Tal princípio estruturante do ordenamento jurídico internacional não é incompatível com mutações territoriais $(v . g$., rectificações do traçado de fronteiras), desde que pacíficas, isto é, concretizadas por via de acordo. Tão-pouco contendem com a existência e a identidade do Estado, as disputas territoriais com Estados vizinhos permanecendo uma parcela significativa do território sob controlo do governo - ou as convulsões políticas internas que conduzam a uma mudança de autoridades políticas ( princípio da continuidade do Estado) (M. Shaw e Díez

7 Ibidem, p. 206.

8 Os poderes de soberania, que o Estado exerce no seu território, são inerentes ao Estado, quase comparáveis a um direito de propriedade. A sua extensão e amplitude torna-os assimiláveis a um autêntico jus utendi, fruendi ac abutendi. Já os poderes de jurisdição, que, diversamente, o Estado exerce em espaços que, em rigor, não fazem parte do seu território, são-lhe, expressamente, atribuídos pelo direito internacional com vista à consecução de certos objectivos. Daí que se trate de poderes limitados, funcionalizados ou instrumentais, bem distantes, portanto, de um jus in re clássico.

9 Cfr., sobre a natureza jurídica do território, QUOC DINH/DAILLIER/PELLET, Droit International..., cit., pp. 404-405.

10 Ibidem, p. 403. 
de Velasco $)^{1112}$. No que toca à organização do poder estadual, ou seja, à organização institucional através da qual podem levar-se a cabo, no seio do Estado, as diversas funções de autoridade pública ${ }^{13}$, não está em causa apenas aquilo a que se convencionou chamar o poder executivo, mas sim todo o conjunto de órgãos necessários para o preenchimento das funções legislativa, judicial e executiva - «órgãos, autoridades e poderes que expressam o poder soberano na ordem política e jurídica $\gg^{14}$. De um ponto de vista teleológico, o governo deve revelar-se apto a garantir o cumprimento dos fins próprios do Estado, prodigalizando aos cidadãos (nacionais ou estrangeiros) que se encontrem sob a sua jurisdição os serviços públicos idóneos à satisfação das suas necessidades fundamentais (concep̧̧ão funcional do Estado ${ }^{15}$ ). A esta ideia se liga a exigência da efectividade governamental (J. Crawford) - autêntica condição jurídica da existência do Estado - a qual impõe que o Estado dê mostras de uma capacidade efectiva para levar a cabo todas as funções conaturais ao poder soberano, designadamente a manutenção da ordem e da segurança, no plano interno, e o estabelecimento de relações com os seus pares, no plano externo, com a correlativa observância dos compromissos e obrigações internacionais daí resultantes.

Pode, pois, concluir-se que a falta de uma forma organizada de governo num determinado território impede que esse território seja o suporte físico de um Estado, o que, naturalmente, pondo em causa o sobredito princípio da integridade territorial, constitui um entrave à existência de uma entidade soberana ${ }^{16}$.

11 Neste sentido, também, FIEDLER, Das Kontinuitätsprinzip im Völkerrecht, Colónia, 1978.

12 Por ex., em finais do séc. XIX, o Paraguai viu-se amputado de cerca de dois terços do seu território, em favor da Argentina, havendo, não obstante, subsistido enquanto Estado soberano, com a sua personalidade jurídica própria.

13 Cfr. GONZÁLEZ CAMPOS/SÁNCHEZ RODRÍGUEZ/SÁENZ DE SANTA MARIA, Curso de Derecho Internacional Publico, $4^{a}$ ed., Civitas, Madrid, 1998, p. 413.

14 Ibidem, p. 413.

15 De harmonia com esta concepção, o Estado converte-se em instituição passível de ser instrumentalizada em benefício das necessidades e aspirações de todos e de cada um dos seres humanos (ALBERT JORDÀ), deixando de ser um sujeito cuja personalidade tem um valor intrínseco e é um fim em si mesma. Cfr. Albert GALINSOGA JORDÂ, «El Concepto de Soberania en el Derecho Internacional Actual», in ..., pp. 338 e ss..

16 Bem ilustrativo, a este respeito, é o caso do Saara Ocidental, em cujo âmbito o Tribunal Internacional de Justiça haveria de afirmar que a determinadas tribos ou grupos nómadas, dotados de alguma organização social e política, é legítimo reconhecer um certo grau de personalidade jurídica. 
Mas, justamente, só poderá falar-se em Estado quando o poder exercido sobre o território estadual for um poder soberano. Ora, o que significa, afinal, a soberania? Quais os seus corolários principais? De há muito que cessaram de emblemar essa majestas estadual a pena de morte no interior e o jus ad bellum no exterior (Enzensberger). Paulatinamente, o conceito de soberania foi-se relativizando ao compasso do enfraquecimento do Estado-nação, o que não pode, evidentemente, dissociar-se da tendência para a diluição do poder deste em espaços políticos e económicos de integração - por vezes, corporizados, no plano institucional, em organizações supranacionais espaços esses que alguns já apelidaram, sugestivamente, de «constelações pós-estaduais» ${ }^{17}$.

Continua, porém, a ser essencialmente válida a asserção de que, enquanto entidade soberana, o Estado não está organicamente subordinado a qualquer outro sujeito de direito. Talvez por isso, na jurisprudência internacional, se faça equivaler a soberania à independência. Ficou célebre, a este respeito, a formulação utilizada pelo juiz/árbitro Max Huber, no caso das Ilhas de Palmas: «la souveraineté dans les relations entre États signifie l'indépendence». E a independência, tal como definida no Projecto de Declaração sobre os Direitos e Deveres do Estado, eleborado em 1949 pela Comissão de Direito Internacional, reconduz-se à capacidade patenteada pelo Estado de assegurar o seu próprio bem-estar e desenvolvimento sem interferências ou ingerências externas, nomeadamente de outros Estados ${ }^{18}$. Para além disso (et pour cause...), decorre igualmente da soberania a liberdade, reconhecida à população estadual, de escolha do regime político, económico e social que melhor corresponda às suas aspirações, sem interferência estrangeira (autodeterminação interna, consubstanciada no princípio da autonomia constitucional e politica), liberdade essa apenas limitada pelo direito internacional imperativo (jus cogens).

\footnotetext{
A ausência de um governo no sentido apontado, parece, todavia, entibiar fortemente a aspiração à condição estadual. Veja-se sobre o assunto, MANUEL DE ALMEIDA RIBEIRO/FRANCISCO PEREIRA COUTINHO, Jurisprudência Resumida do Tribunal Internacional de Justiça (19472015), Publicações Dom Quixote, 2016, pp. 405 e ss.

17 Apesar disso, parece um exagero manifesto considerar o Estado-nação como uma entidade com uma inelutável vocação de extinção. Cfr., acerca disso, Juan Manuel FARAMIÑÁN GILBERT, «Luces y Sombras de la Globalización», cit, pp. 169 e ss..

18 Cfr., também, GONÇALVES PEREIRA/FAUSTO DE QUADROS, Manual de Direito Internacional Público, $3^{\mathrm{a}}$ edição, Almedina, 1993, pp. 328 e ss.
} 
Um terceiro corolário da soberania que, virtualmente, se traduz numa espécie de "privilégio de execução prévia", consiste na presunção de regularidade ou de licitude dos actos do Estado, muito em especial aqueles que sejam praticados no respectivo território e se inscrevam no âmbito do chamado domínio reservado (conjunto de matérias tão-somente relevantes in foro domestico, relativamente às quais o direito internacional deverá permanecer arredio $)^{19}$. Um controlo apenas subsequente e, as mais das vezes, descentralizado desses comportamentos estaduais quase confere àquela presunção um carácter jure et de jure.

Olhando ao plano internacional, constituem manifestações típicas do poder soberano do Estado, entre outros, o jus tractum, isto é, o direito de concluir tratados ou convenções internacionais; o jus legationis, quer dizer, o direito de enviar e receber agentes diplomáticos; o direito de reclamação internacional, por meio de cujo exercício, junto de determinadas instâncias internacionais (de carácter jurisdicional ou não), poderá o Estado assumir a defesa dos seus direitos; e o jus ad bellum, hoje confinado, ex vi do art. $2 .^{\circ}, \mathrm{n}^{\circ}$ $4 \mathrm{da} \mathrm{CNU}$, às situações de legítima defesa, abstraindo do sentido e alcance que hodiernamente deve atribuir-se a esse direito inerente ao Estado, consagrado no art. $51 .^{\circ}$ desse mesmo instrumento normativo ${ }^{20}$.

\section{Autodeterminação}

Embora invocado por Lénine, em 1916, numa perspectiva ideologicamente comprometida, com vista a apressar o estertor do Império AustroHúngaro e, bem assim, do colonialismo tradicional, é amplamente aceite que o princípio da autodeterminação teve nos Catorze Pontos dirigidos ao Congresso pelo presidente norte-americano Woodrow Wilson o seu acto de nascimento ${ }^{21}$.

19 Cfr. QUOC DINH/DAILLIER/PELLET, Droit..., cit., p. 416. Veja-se também, entre nós, Jorge BACELAR GOUVEIA, Manual de Direito Internacional, $5^{a}$ edição, Almedina, 2017, p. 465.

20 Cfr. GONÇALVES PEREIRA/FAUSTO DE QUADROS, Manual..., cit., pp. 331-332.

21 Cfr. EDWARD McWHINNEY, Self-determination of peoples and plural-ethnic States, RCADI, Tome 294, 2002, p. 177. 
Verdade que, ao sopro de impulso, tal princípio começou por achar-se circunscrito ao terreno das meras proclamações políticas. Atestam-no a circunstância de haver sido rejeitada a sua inclusão no Pacto da Sociedade das Nações e o facto de só muito limitadamente, até ao advento da Segunda Guerra Mundial, a ideia de autodeterminação ter contribuído para a resolução de conflitos internacionais no continente europeu.

Proclamado na Carta das Nações Unidas, conquanto ao jeito de um princípio programático e escassamente operativo - pense-se, v.g., nos caps. XI e XII, respectivamente, respeitantes a territórios não autónomos e ao regime internacional de Tutela, cuja compatibilização com o $\operatorname{art}, 1^{\circ}, \mathrm{n}^{\circ} 2$, não se afigura isenta de escolhos - , ele assume hoje a natureza de jus cogens, ainda que, relativamente ao alcance da sua vertente externa, se registe assinalável incerteza. É sabido que a ambiguidade do regime vertido na $\mathrm{CNU}$ traduz o frágil consenso que, à época, foi possível alcançar, a partir dos pontos de vista divergentes dos grupos de Estados que compunham a comunidade internacional.

Se os países socialistas, inspirados pelas ideias de Lénine, encareciam a vertente externa da autodeterminação, transmutando-a num postulado anticolonialista, e concebiam a vertente interna como um veículo para a realização do socialismo no mundo, os países do Terceiro Mundo, exaltavam igualmente, por sua vez, a dimensão externa do direito de livre disposição, alargando-a, todavia, a duas outras categorias de povos não autónomos: a dos que estivessem sujeitos a ocupação estrangeira e a dos que se encontrassem submetidos a regimes fundados numa discriminação racial institucionalizada. A existência de determinadas estruturas de opressão erige-se, por conseguinte, em traço comum de ambas as concepções. Já os Estados ocidentais sobraçavam, preferencialmente, a vertente interna da autodeterminação, ligando-a ao princípio democrático e às liberdades individuais: direito de livre escolha de um determinado regime político e dos governantes julgados capazes de assegurar o bem-estar e a prosperidade da população ${ }^{22}$

Seriam sucessivas resoluções da Assembleia Geral das Nações Unidas, normas convencionais e pronúncias corroborantes do Tribunal Internacional de Justiça a contribuir, de forma decisiva, para que o princípio da

22 Veja-se, a propósito, o nosso Direito..., cit., p. 316. 
autodeterminação se convertesse em autêntico direito universal, integrante do núcleo restrito dos princípios fundamentais do direito internacional. ${ }^{23}$ No que toca às resoluções da $\mathrm{AG}$, quatro delas assumiram especial proeminência: a Res. 1514 (XV), a Res. 1541 (XV), a Res. 1654 (XVI) e a Res. 2625 (XXV). A primeira, intitulada Declaração sobre a concessão da independência aos paises e povos coloniais, e que ficara, sintomaticamente, conhecida como "Carta ou Declaração da descolonização", foi adoptada em 14 de Dezembro de 1960, numa altura em que a maioria de Estados afro-asiática na AG, apoiada então pelos países do antigo bloco de leste, favoreceu o seu teor demasiado voluntarista. Nela se proclama, com efeito, constituir a autodeterminação um direito de todos os povos $(\$ 2)$, não devendo a falta de preparação nos campos político, económico ou social, ou o do ensino, pretextar o retardamento da independência $(\$ 3)$; o que, acrescente-se, não deixaria de valer também para os territórios não autónomos e sob tutela a que se reportam os Caps. XI e XII da CNU ( $\$ 5)$.

A Res. 1541 (XV), adoptada apenas um dia depois, teve o condão de sofrear, ainda que em escassa medida, as insensatas tentações de autêntica «héterodeterminação ${ }^{24}$ » que transpareciam da Res. 1514 (XV), ao alargar, no Princípio VI respectivo, as modalidades admissíveis de exercício do direito de livre disposição dos povos não autónomos: para além da independência (solução única na Res. 1514 (XV), encontram-se aí, na verdade, contemplados os estatutos alternativos da associação e da integração ${ }^{25}$.

23 , p. 316. Veja-se também Edward McWHINNEY, Self-determinations of peoples..., cit., pp. 178181 .

\section{Cfr. GONÇALVES PEREIRA/FAUSTO DE QUADROS, Manual..., cit., p. 541.}

25 Se relativamente à independência - considerado o desfecho "natural" do exercício do direito à autodeterminação - as demandas procedimentais da ONU, no que toca às formas e aos mecanismos de auscultação da população, não são particularmente exigentes, outro tanto não se dirá acerca dos estatutos (mais atípicos) da associação e da integração. Assim, estipula o Princípio VII da Res. 1541 $(\mathrm{XV})$ que a associação deve resultar de uma escolha livre e voluntária da população do território em questão, exprimida através de métodos democráticos e largamente difundidos. Uma vez consumada tal escolha, deverá esse estatuto assentar no respeito pela individualidade e pelas características culturais do território e respectiva população, à qual é conferido o direito de determinar a sua própria constituição sem ingerências externas. Acresce que à associação é atribuído um carácter reversível, conservando as populações o direito de modificar o estatuto do território. No que tange, por seu turno, à integração, determina o Princípio IX da mesma Res. que o território integrado deverá ter alcançado um estádio avançado de autonomia, com instituições políticas livres, de tal forma que a população tenha a capacidade de fazer a sua escolha, com pleno conhecimento de causa, através de métodos democráticos assentes no sufrágio universal dos adultos (sistema "um homem um voto"). 
A terceira (Res. 1654 (XVI)), reveste-se de indiscutível importância no plano simbólico: por seu intermédio, foi criado o "Comité de Descolonização", ou "Comité dos 24", o que implicou uma clara subalternização e perda de importância do Conselho de Tutela.

Por fim, a Res. 2625 (XXV), ou "Declaração dos sete princípios", integrando o direito dos povos à autodeterminação no elenco dos princípios fundamentais reguladores das relações de amizade e cooperação entre os Estados, admite o seu exercício em termos particularmente amplos: independência, associação, integração ou "qualquer outro estatuto politico livremente decidido pelo povo”. Parece, portanto, claro que ao direito à autodeterminação corresponde, do lado do Estado administrante, um dever de auscultação ou consulta da população, através de mecanismos democráticos de consulta popular organizados e/ou supervisionados pela ONU e, eventualmente, em concomitância, por organizações regionais ${ }^{26}$.

Certo é, contudo, que a liberdade reconhecida a um povo subjugado para decidir o seu futuro deverá ser exercida num quadro de total transparência e pleno esclarecimento das populações. Para esse fim, assume-se, inter alia, como indispensável a libertação de presos políticos, a participação de exilados no processo, o respeito pelos direitos e liberdades de participação política designadamente, as liberdades de associação, reunião e expressão - , a informação completa e tempestiva da população acerca da técnica de votação que vai ser utilizada e do significado da mesma, etc. ${ }^{27}$. Incontroverso é, outrossim, que, tratando-se de povos colonizados, a referida consulta popular deveria ser levada a cabo no perímetro das fronteiras coloniais (ainda que reputadas de arbitrárias), em conformidade com o princípio uti possidetis, com vista a proteger o futuro Estado (sendo esse o caso) de hipotéticas tentativas de desmembramento do seu território ${ }^{28}$. Se as normas convencionais - em particular, os Pactos Internacionais sobre direitos humanos, adoptados sob

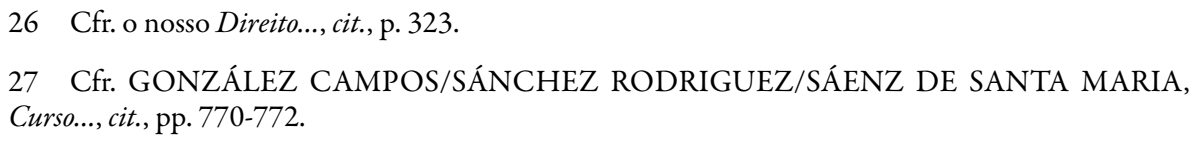

28 Veja-se, uma vez mais, nestes precisos termos, o nosso Direito..., cit., p. 324. Cfr. também, acerca da doutrina uti possidetis, da sua evolução ao longo do tempo e da sua diversa compreensão nos continentes europeu, americano e africano, Edward McWHINNEY, Self-determination of peoples..., cit., pp. 229-235. 
a égide das Nações Unidas - como que "codificaram" uma parte do acervo de normas consuetudinárias nascentes em matéria de autodeterminação, importa, igualmente, não silenciar o contributo do Tribunal Internacional de Justiça para o reforço da opinio juris que entre os Estados se formara já acerca do princípio da livre disposição dos povos. Contributo esse, de início, algo tíbio, mormente no caso do Sudoeste Africano, e, mais tarde, já de maior afoiteza, nos casos da Namíbia, do Sahara Ocidental e de Timor-Leste ${ }^{29}$.

Para além da sua originária dimensão política, o direito dos povos à autodeterminação ver-se-ia, a partir de meados da década de sessenta do séc. XX, acrescido de uma - hoje muito valorizada - vertente económica, consubstanciada na afirmação da soberania permanente dos povos sobre os seus recursos naturais. Com efeito, diversas resoluções da ONU, bem como a adopção da Carta dos Direitos e Deveres Económicos dos Estados, em 1974, haviam constituído o quadro normativo indispensável à instauração de uma Nova Ordem Económica Internacional, forte e reiteradamente reivindicada pelos Estados mais desfavorecidos. Ora, as implicações em sede de autodeterminação ressaltavam claras: a intangibilidade das riquezas e recursos naturais dos povos que se aprestavam para exercer (ou que tivessem já exercido) o seu direito de livre disposição visava (visa) assegurar-lhes os meios do seu desenvolvimento efectivo e garantir-lhes a sua independência económica face a eventuais práticas "neocolonialistas".

O progressivo guindamento do princípio da autodeterminação dos povos ao patamar do jus cogens repercutir-se-ia, à guisa de recíprocas interdependências, em outros princípios e institutos do direito internacional, cujos sentido e alcance tradicionais se viram, repentinamente, reconfigurados. Referimonos, entre outros, à proibição do recurso à força, ao dever de não ingerência, à legítima defesa, às reações de Estados terceiros face à repressão, pela força, daquele princípio, etc. ${ }^{30}$.

Hoje, porém, com o fim do colonialismo tradicional e com o carácter, apesar de tudo, residual das outras situações de titularidade do direito de livre

29 Neste último - o caso Timor Gap —, que dizia directamente respeito a Portugal —, o Tribunal não se coibiu de afirmar que o princípio da livre determinação dos povos foi reconhecido na Carta das Nações Unidas e na jurisprudência do Tribunal e que se trata de um dos princípios fundamentais do direito internacional contemporâneo (C.I.J, Recueil, 1995, p. 102).

30 Cfr. Francisco FERREIRA DE ALMEIDA, Direito..., cit., p. 320. 
disposição externa reconhecida a certos povos não autónomos, há, nesta sede problemática, umas quantas interrogações que, sobretudo, nos interpelam, a saber: o que "sobra", actualmente, do princípio da autodeterminação? A que estruturas de opressão se aplica? Comportará ele, no limite, um direito à secessão dentro de Estados soberanos?

É sabido que, afora os casos de dominação colonial, de ocupação estrangeira e de regimes assentes num apartheid racial, são, cada vez mais intensamente, as minorias e os povos indigenas a reivindicarem a outorga de um direito à autodeterminação - o que se volve na comprovação de que, progressivamente, a autodeterminação externa foi cedendo o passo à autodeterminação interna ${ }^{31}$.

No que àquelas diz respeito, podem, na esteira de Capotorti e Deschênes, definir-se como grupos que, no seio de um determinado Estado, possuem uma expressão numérica muito inferior à da restante população - com a qual, em todo o caso, partilham a mesma nacionalidade - e que, em razão de características étnicas, religiosas e/ou linguísticas que lhes conferem uma evidente homogeneidade, aspiram, solidariamente, à preservação da sua cultura, das suas tradições (numa palavra, da sua identidade) e, por conseguinte, a um certo grau de autonomia, num quadro de igualdade de direitos com a população maioritária ${ }^{32}$.

31 Veja-se, a propósito, José Alberto de AZEREDO LOPES, «Direito de autodeterminação dos povos», in Regimes Jurídicos Internacionais (J. A. AZEREDO LOPES — coordenador), Universidade Católica - Editora Porto, 2020, pp. 585 e ss.

32 Diga-se que, durante muito tempo, o direito internacional não entrou no terreno "pantanoso" da protecção das minorias - em tese, potenciador de conflitos entre nacionais do mesmo Estado. Com efeito, em última análise, estão em causa direitos reconhecidos aos membros de grupos minoritários que, perante comportamentos abusivos por parte da maioria, serão feitos valer contra o seu próprio Estado, com tudo o que isso tem de potencialmente disruptivo. A progressiva internacionalização do problema viria, todavia, a ocorrer ao compasso da criação de certos Estados e da rectificação artificial do traçado de fronteiras de outros, após a Primeira Guerra Mundial, em claro desserviço ao já atrás aludido princípio das nacionalidades. Descaso esse que viria a transformar algumas zonas da Europa numa autêntica "manta de retalhos". Daí a necessidade, que paulatinamente se foi robustecendo, de serem criados mecanismos tendentes a assegurar uma protecção efectiva de alguns direitos das minorias, designadamente o direito à nacionalidade, o direito ao uso da língua materna (v.g., em matéria de relações comerciais, de religião, de ensino, de publicações, etc.), o direito à propriedade privada, o direito à liberdade de culto religioso e, em geral, o direito a um tratamento igualitário (não discriminatório) face aos nacionais maioritários. Não foi senão, contudo, a partir da segunda metade do séc. XX e, muito em especial, com a adopção do Pacto Internacional de Direitos Civis e Políticos, de 1966 (no qual, com carácter pioneiro, se atribuem, directamente, direitos às minorias qua tale), que se passou da fase de uma mera proteç̧ão pela via diplomática para a do reconhecimento de um certo grau de personalidade jurídica internacional (cfr. art. 27..$^{\circ}$ respectivo). Cfr., sobre este ponto, GONÇALVES PEREIRA/FAUSTO DE QUADROS, Manual..., cit., pp, 387-391; e JORGE MIRANDA, Curso de Direito Internacional Público, 6a edição, Principia 2016, pp. 319-322. 
No que toca à titularidade dos direitos reconhecidos internacionalmente às minorias, parece não ser inconciliável a sua dúplice dimensão individual e grupal ${ }^{33}$. Quer dizer, os direitos (individuais) dos membros de um grupo minoritário são, por vezes, exercidos em comunidade (Capotorti), pois que se trata de direitos baseados nos interesses de uma colectividade. O que redunda até - haverá de convir-se - numa certa "despersonalização" do titular do direito, porquanto não é o indivíduo $\mathrm{A}, \mathrm{B}$ ou $\mathrm{C}$, em si e por si mesmo considerado, que está prioritariamente em jogo, mas sim o indivíduo enquanto membro de um determinado grupo minoritário. É, pois, justamente, nessa qualidade (na medida dessa pertença) que ele se torna beneficiário da protecção outorgada pelos textos normativos internacionais. Paradoxalmente, no entanto, a lógica colectiva a que acabámos de aludir não deixa de constituir um necessário ponto de partida para que seja assegurada uma efectiva protecção dos direitos humanos individuais ${ }^{34}$. Relativamente, por outro lado, aos povos indígenas ${ }^{35}$, estamos em presença de comunidades — aliás, em grande número - às quais, nas suas várias manifestações concretas, os conceitos de povos e de minorias não se afeiçoam completamente ${ }^{36}$.

Dotados, efectivamente, de um estatuto que se não pode, por enquanto, equiparar, sem mais, àquele que o art. $10^{\circ}$ do Pacto Internacional dos Direitos Civis e Políticos (PIDCP) reconhece aos povos não autónomos, mas que parece também não poder circunscrever-se ao núcleo relativamente limitado de direitos internacionalmente outorgados às minorias no art. $27 .^{\circ}$ desse mesmo instrumento normativo, compreende-se que os povos indígenas relutem, consistentemente, em ser incluídos nesta última categoria ${ }^{37}$. Seja como

33 Cfr. José Alberto de AZEREDO LOPES, Entre solidão e intervencionismo - Direito de autodeterminação dos povos e reaçôes de Estados terceiros, Porto, 2003, pp. 237 e ss..

34 Ibidem, p. 243.

35 Um conceito pós-colonial, nas palavras de Luis Rodríguez Piñero. Cfr. Luis RODRÍGUEZPIÑERO, Indigenous peoples, postcolonialism and international law, Oxford University Press, 2005, p. 4.

36 Tal singularidade leva alguns autores a falarem num tertium genus entre as minorias e os povos. Releve-se, ainda assim, que, durante muito tempo, foram de tipo colonial as relações dos povos indígenas com o centro de poder, facto este assinalado na Declaração das Nações Unidas sobre Povos Indígenas, de 2007.

37 Até pela importância do elemento território, isto é, da estreita ligação que existe entre os povos indígenas com o espaço envolvente, algo que não se verifica (ou não se verifica com o mesmo grau ou intensidade) no caso das minorias. Veja-se, a propósito, P. THORNBERRY, International law and 
for, talvez adquira propósito aduzir-se que as novas dinâmicas do princípio da autodeterminação, catalisadas pelo relacionamento entre os vários sujeitos (tradicionais e mais recentes) do direito internacional, o foram, progressivamente, tornando mais complexo e, nessa medida, menos "monocromático", permitindo-lhe actualmente acomodar as pretensões, quer das minorias, quer dos povos indígenas, liberto da linearidade (simplicidade) que o caracterizava no contexto colonial. A "reciclagem" do direito dos povos à autodeterminação, de que procurámos dar conta resumida, coloca, no entanto, uma questão perturbadora: poderá hoje admitir-se a secessão como forma de autodeterminação? A situação da Escócia no seio do Reino Unido, primeiro, e as convulsões recentemente vividas na Catalunha, depois, cujo desenlace se afigura ainda de muito difícil vislumbre, vieram, entrementes, conferir ao problema uma indiscutível actualidade.

Faz-se mister aludir à questão autonomamente.

\section{SeCESSÃo}

Compreende-se que, no plano internacional, se olhe para a secessão como uma malsinada causa de desmembramento do território estadual. $\mathrm{O}$, atrás aludido, princípio da integridade territorial assim o determina. Dele decorre, com efeito, uma ideia de preservação dos limites territoriais originários do Estado, isto é, contemporâneos da respectiva formação, pois que a garantia dessa indivisibilidade evitará dinâmicas disruptivas, favorecendo, consequentemente, do mesmo passo, a manutenção da paz e da segurança internacionais.

Que o Direito e a prática internacionais não revelam uma aceitação benévola das tentativas (endógenas ou exógenas) de desagregação, desmembramento ou

rights of minorities, Oxford, 1991, p. 331. De acordo com a proposta de Martinez Cobo, antigo relator especial da Nações Unidas, são quatro os elementos que permitem caracterizar um povo indígena: a anterioridade histórica, uma cultura distinta, a posição não dominante e a auto-identificação. Tais elementos predicativos estão na base de uma ideia de soberania divisivel e de um proclamado (em alguns sectores da comunidade internacional) direito a autonomia (com ou sem governo próprio), em todo o caso não confundível com independência ou secessão. Rodriguéz-Piñero, por seu turno, alude a um regime sui generis de protecção dos povos indígenas, consubstanciado num standard minimum de comportamentos exigido, quer a actores estaduais, quer a actores não estaduais, o qual recobre áreas como a não discriminação, a cultura indígena, os direitos sobre a terra e respectivos recursos, o bemestar social e a governação. Cfr. Luis RODRIGUÉZ-PIÑERO, Indigenous peoples..., cit., p. 7. 
dissolução territoriais, em nome de um pretenso direito à autodeterminação, atestam-no diversos casos ocorridos da segunda metade do séc. XX em diante ${ }^{38}$.

Constituem elementos do conceito de secessão um propósito de separação territorial, de carácter unilateral (porque exprimido contra a vontade do Estado cuja integridade é posta em causa) e, por via de regra, com o objectivo de criar um novo Estado ${ }^{39}$.

Tendem, em todo o caso, a não confundir-se com a secessão as figuras do irredentismo e da unificação. No primeiro caso, a pulsão separatista resulta, não da vontade de constituir um novo Estado, mas sim da tentativa de integrar um estado preexistente, cuja actuação, enquanto parte interessada, consubstancia, aliás, as mais das vezes, violação do princípio da não ingerência ou não intervenção (veja-se o exemplo recente da Crimeia e da intervenção das forças russas no processo ${ }^{40}$. No segundo, trata-se habitualmente de grupos dispersos ou disseminados por vários Estados, que almejam separar-se destes, com vista à sua agregação num único Estado independente (v.g., o projecto de unificação dos curdos $)^{41}$.

38 Cfr. José Alberto de AZEREDO LOPES, «Direito de autodeterminação...», cit, pp. 615 e ss.. O autor passa em revista, designadamente, os casos do Katanga (República do Congo), da Rodésia (actual Zimbabué), do Chipre ("República Turca de Chipre do Norte) e da exJugoslávia. Quando a este último, recorda que em em cima da mesa estavam duas teses distintas: uma (defendida pela Sérvia) que encarava como actos de secessão a independência das várias Repúblicas que integravam o território da antiga Jugoslávia, continuando, todavia, a existir o Estado originário; e outra (defendida pela Bósnia-Herzegovina, Croácia, Eslovénia Macedónia e Montenegro), que, ao invés, sustentava estar-se perante um fenómeno de desintegração da antiga República Federativa Socialista da Jugoslávia. Esta última haveria de ser a posição adoptada pela Comissão Arbitral encarregada de apreciar o caso. É certo que, como sublinha o autor, a tese da desagregação (ou dissolução) obviava ao inconveniente de a Comissão ter de se confrontar com diversos actos de secessão, mas será bom não esquecer que a Convenção Sobre Sucessão de Estados Em Matéria de Tratados, de 1978, consagra também como categoria admissível de sucessão de Estados a separação, continuando a existir (ou não) o Estado predecessor. Na verdade, independentemente da forma como, do ponto de vista jurídico, possa ser valorada uma situação desse tipo, é inquestionável que, materialmente, em tal hipótese, ocorre uma operação de sucessão. Entretanto, alguns anos mais tarde, a Convenção Sobre Sucessão de Estados Em Matéria de Propriedade, Arquivos e Dívidas (1983) viria a consagrar a categoria da dissolução, o que significa que a separação apenas assume, actualmente, relevo autónomo nos casos em que, justamente, o Estado predecessor continua a existir.

39 Elementos estes identificados pelo Supremo Tribunal do Canadá, no caso do Quebeque. Ibidem, p. 619.

40 Veja-se, sobre o caso da Crimeia, Christian MARXSEN, Territorial Integrity in International Law - Its Concept and implications for Crimea, ZaöRV, vol. 73, 2015, p. 26.

41 Ibidem, p. 26. Ao contrário de alguma doutrina, entendemos, no entanto, que o fenómeno da secessão pode, ao menos teoricamente, ter na sua base conflitos desencadeados por insurrectos ou 
Casos, relativamente (ou muito) recentes, como os do Quebeque, do Kosovo, da Escócia e da Catalunha, nas suas relações com os princípios da autodeterminação dos povos e da integridade territorial dos Estados, abrem caminho a umas curtas reflexões sobre o problema que agora nos ocupa: o de um pretenso direito à secessão no direito internacional, em situações muito específicas.

E a primeira ideia a reter é a de que as situações de descolonização, que, durante muito tempo, praticamente exauriram as potencialidades de aplicação e de exercício do direito de autodeterminação externa, não podem reconduzir-se a fenómenos de secessão, tal como acima os caracterizámos. Assumem-se, realmente, como traços fundamentais do conceito de território colonial o respectivo carácter geograficamente separado (da metrópole), a natureza étnico-culturalmente distinta da população nele instalada e a existência de um regime político, económico e social discriminatório relativamente à população autóctone ${ }^{42}$. Ora, é manifesto que (pelo menos) o primeiro elemento se encontra ausente ou arredio dos casos típicos de secessão territorial. Acresce que o direito internacional reputa sempre de ilícita a relação (entre a metrópole e a população dominada) subjacente a um contexto colonial - algo que não se verifica, necessariamente, nos casos, não equiparáveis, de relação conflitual entre o centro do poder e as periferias ou regiões, dentro de determinados Estados soberanos, casos esses que fundam, amiúde, pretensões separatistas (vejam-se os casos paradigmáticos da Escócia e da Catalunha). Donde serem, em princípio, reguladas, quase exclusivamente, pelo direito interno (constitucional) as relações entre o Estado e o grupo (ou região) que pretende "emancipar-se”. A segunda ideia que importa sublinhar é a de que, num tempo de

\footnotetext{
beligerantes. De facto, se, frequentemente, o grupo que se rebela, visa, tão-somente, pôr em causa a legitimidade das autoridades oficiais do Estado no seio do qual desenvolve a sua luta, pretendendo, a prazo, alcançar, uma substituição de governos, nada impede que o seu objectivo seja ab initio (ou se torne, posteriormente) mais ambicioso, passando pela cisão do território estadual e pela criação de um novo Estado soberano. Ambas as hipóteses têm importantes implicações em sede de reconhecimento (de governos, no primeiro caso, e de Estado, no segundo). Veja-se, acerca deste ponto, o nosso Direito Internacional..., cit., pp. Veja-se também sobre a secessão e conceitos afins ou aparentados, Milena STERIO, Self-Determination and Secession under International Law: The New Framework, ISLAJICL, Vol 21, 2015, pp. 293 e ss..
}

42 Cfr., a propósito, a supracitada Resolução 1541 (XV), da AG das Nações Unidas, de 15 de Dezembro, de 1960. 
enfraquecimento do Estado enquanto realidade histórica, jurídica e política ${ }^{43}$ e de recrudescimento, um pouco por toda a parte, de nacionalismos exacerbados, alguns deles frondejando em jeito de contrabalanço à uniformização cultural, artificialmente imposta por uma globalização infrene - movimento este já designado por "pós-moderno neo-tribalismo" (T. Franck) —, impõe-se revalorizar o princípio da integridade territorial dos Estados, sob pena de se caucionar ou promover, irresponsavelmente, uma indesejável "balcanização" da sociedade internacional.

A terceira ideia, é a de que as considerações supra-expendidas encontram decisivo apoio no parágrafo 7 da Resolução 2625 da AG das Nações Unidas, o qual reza assim:

«Nada nos parágrafos precedentes poderá ser interpretado como autorizando ou encorajando uma acção, qualquer que seja, que possa desmembrar ou ameaçar, total ou parcialmente, a integridade territorial ou a unidade política de qualquer Estado soberano e independente que aja em conformidade com o princípio da igualdade de direitos e o direito dos povos à autodeterminação enunciado acima e dotado, por conseguinte, de um governo que represente o conjunto do povo pertencente ao território, sem distinção de raça, credo ou cor».

Sintetizando, poder-se-á dizer assim: a integridade territorial e a independência política do Estado constituem um limite inultrapassável, uma espécie de "linha vermelha", para o direito dos povos à autodeterminação. Ponto é que os Estados respeitem tal direito, na sua vertente interna, e que representem o conjunto do povo instalado nos respectivos territórios, sem distinção de qualquer tipo ${ }^{44}$.

Esta ressalva, contida na parte final do parágrafo 7 da “Declaração dos sete princípios” ${ }^{45}$, deixa margem para conjecturar a hipotética admissibilidade,

43 Cfr. Juan Manuel FARAMINAN GILBERT, «Luces y Sombras de la Globalización», cit., pp. 169 e ss.

44 Em 1995, por ocasião do seu $50^{\circ}$ aniversário da ONU, a AG, perseverou na afirmação dessa ressalva, substituindo, todavia a expressão «... sem distinção de raça, credo ou cor » pela formulação, mais abrangente, «sem distinção de qualquer tipo».

45 Designação pela qual é também conhecida a Resolução 2625 , em virtude de serem sete os princípios fundamentais de direito internacional nela enunciados. 
em casos extremos, daquilo que pode qualificar-se como secessão-remédio ${ }^{46}$. Do que se trata?

Em causa estarão aquelas situações de ruptura irreversível dos laços sociais e comunitários dentro de um Estado soberano, ruptura essa ocasionada por violações sistemáticas, reiteradas e em larga escala dos direitos dos indivíduos pertencentes a um determinado grupo, etnia ou região. Exigese, além disso, que tais práticas ou comportamentos sejam levados a cabo de harmonia com uma ideologia, um plano ou uma acção das autoridades oficiais desse Estado. E isto de tal feição que se torne, virtualmente, impossível a convivência futura entre o centro de poder e essa ou essas periferias. Numa palavra, estamos porventura a falar da prática contra um certo agrupamento, selecionado como alvo, dos crimes de genocídio ou contra a humanidade, ou pelo menos, da tentativa de alcançar um território "etnicamente puro”. Dito de outra forma, só uma violação do direito internacional imperativo (jus cogens) poderá dar azo a uma secessão em que o direito internacional cooneste a postergação, in casu, do princípio da integridade territorial, em nome da protecção de valores também fundamentais para a comunidade internacional ${ }^{47}$.

Recairíamos, por conseguinte, nessa eventualidade, no terreno da sobredita secessão-remédio, quer dizer: não uma secessão que à guisa de sanção ou punição fosse imposta ao Estado autor das violações grosseiras dos direitos humanos, mas sim uma secessão encarada como solução de ultima ratio em ordem a garantir a protecção do grupo vítima de tais abusos $^{48}$. Reitera-se, pois, que o direito dos povos à autodeterminação não comporta, jamais, o direito à secessão unilateral, mas sobre esta pode, em certos casos-limite, não incidir um juízo de ilicitude, designadamente quando se afirme como o derradeiro recurso para evitar a barbárie ${ }^{49}$. Com

46 Cfr., sobre o assunto, Glen ANDERSON, Unilateral Non-Colonial Secession and Internal SelfDetermination: a Right of Newly Seceded Peoples to Democracy, AJICL, Vol. 34, 2017, pp. 31 e ss.

47 Sobre o conceito de jus cogens e as suas principais implicações, veja-se o nosso Mutações sistémicas e normativas no direito internacional em face de novos desafios, Scientia Iuridica, Maio-Agosto 2011, Tomo LX, número 326, pp. 225 e ss.

48 Cfr. J. A. AZEREDO LOPES, «Direito de autodeterminação...», cit., p. 628.

49 Como, notoriamente, sucedeu no caso da independência do Bangladesh, em 1971, na sequência de uma guerra na qual viria a ser derrotado o Paquistão Ocidental. Ibidem, p. 627. 
base neste pressuposto, não guardamos qualquer rebuço em afirmar (é, de resto, bom de ver) que, nem a situação da Escócia no seio do Reino Unido, nem a da Catalunha em Espanha, se adequam a este requisito conformador $^{5051}$.

\section{RECONHECIMENTO}

Uma coisa é certa: quer estejamos perante uma secessão legítima, quer nos confrontemos, ao invés, com uma secessão contra legem, a nova entidade territorial debater-se-á (mais neste caso do que naquele) com um problema nada negligenciável. Referimo-nos ao seu reconhecimento internacional. Como é sabido, o instituto do reconhecimento assume uma importância crucial numa sociedade quase desprovida (ou, pelo menos, escassamente provida) de representação orgânica e institucional. Mais exactamente, o reconhecimento, conquanto corresponda ao exercício de uma competência essencialmente discricionária, permite joeirar os factos, conferindo alguma estabilidade às relações internacionais e evitando, em concreto, que, a respeito da mesma situação, possam os Estados adoptar comportamentos oscilantes, díspares ou contraditórios ao longo do tempo.

Enquanto acto jurídico unilateral do Estado, o reconhecimento (desde que preenchidos os requisitos da imputabilidade, da oponibilidade, da autonomia e da publicidade ${ }^{52}$ ) é fonte de direito internacional, isto é, por seu intermédio, são criados direitos e/ou obrigações, quer para terceiros, quer para o próprio sujeito que o adopta.

50 Coisa diferente é, naturalmente, uma separação territorial negociada, isto é, concretizada por via de acordo. Ainda assim, não deve ter-se por excluído que mesmo uma secessão unilateral, não respaldada no direito internacional, possa, a prazo, se, entretanto, consolidada ou estabilizada, acabar por ser aceite e reconhecida por força do princípio da efectividade, cuja importância não se desvaneceu completamente na passagem do direito internacional clássico para o direito internacional moderno.

51 Não contradiz o que acabámos de afirmar o Parecer lavrado pelo Tribunal Internacional de Justiça, em 2010, sobre a declaração unilateral de independência do Kosovo. Com efeito, nessa pronúncia algo sibilina, o Tribunal não discutiu (como, porventura, deveria) a licitude (ou ilicitude) da secessão do Kosovo. Limitou-se, isso sim, a considerar não desconforme com o direito internacional a declaração unilateral de independência desse território - questão esta situada a jusante e cuja análise correspondia (literal e estritamente) à questão que lhe havia sido colocada pela Assembleia Geral.

52 Sobre o respectivo significado, cfr. o nosso Direito Internacional..., cit., pp. 188-189. 
Através do reconhecimento, um Estado, não havendo participado no surgimento de determinada situação e reputando-a de lícita ou legítima à luz do direito internacional, aceita (ou implicitamente admite) os efeitos jurídicos dela decorrentes, consentindo, pois, que lhe sejam oponíveis. Trata-se, em síntese, de, jure imperii, conferir significação "legal” (M. Shaw) a certos factos da vida internacional.

Várias são as situações passíveis de reconhecimento, mas, de entre elas, assumem especial relevo a do reconhecimento de Estados e a do reconhecimento de governos.

Relativamente ao Estado, coloca-se o problema de saber quando nasce a sua personalidade jurídica. A resposta a esta questão passa pela natureza e alcance do acto de reconhecimento. A este respeito, encontram-se, tradicionalmente, duas concepções divergentes na doutrina; a teoria constitutiva ou atributiva e a teoria declarativa ${ }^{53}$.

De acordo com a primeira, defendida pelos autores voluntaristas clássicos (Cavaglieri, Triepel, Jellinek, etc.), a aparecimento de um novo Estado na comunidade internacional depende da aceitação (rectius, do consentimento) dos Estados preexistentes, exprimida, justamente, através de um acto discricionário (salvo violação do jus cogens) de reconhecimento. $\mathrm{Na}$ ausência deste, portanto, a personalidade jurídica do Estado não lograria formar-se, pois que seria o reconhecimento a constitui-la (ou a atribui-la) ao novel sujeito primário.

Bastará, contudo, pensar-se na nublosa situação em que mergulharia um Estado reconhecido por uns, mas não por outros (que consequências adviriam de uma tal capitis deminutio, v.g., no plano da respectiva vinculação às normas de direito internacional ou em sede de responsabilidade internacional?), para que, no que toca a esta directriz, formulada nos termos acima descritos, não possamos senão ser assaz reticenciosos.

Já a tese declarativa, hoje amplamente aceite, repousa em pressupostos totalmente distintos. Para os seus defensores, o surgimento de um Estado

53 Vejam-se, a propósito, inter alia, QUOC DINH/DAILLIER/PELLET, Droit International..., cit., pp. 530 e ss.; Albino de AZEVEDO SOARES, Liçôes de Direito Internacional Público, $4^{\mathrm{a}}$ edição, Coimbra Editora, 1988, pp. pp. 203 e ss.; GONÇALVES PEREIRA/FAUSTO DE QUADROS, Manual..., cit., pp. 3053 ss.; Eduardo CORREIA BAPTISTA, Direito Internacional Público Conceito e Fontes, Vol, I, Lex, Lisboa, 1998, p. 395; JONATAS MACHADO, Direito Internacional, Gestelegal, 2020, pp. 250 e ss.; e o nosso Direito Internacional Público..., cit., pp. 258 e ss.. 
resulta de um processo de facto, tratando-se, pois, de uma realidade objectiva, insusceptível de contestação. A personalidade jurídica deriva, por conseguinte, da mera reunião, nessa nova entidade, dos três elementos (população, território e governo) imprescindíveis à constituição do Estado soberano. Através do reconhecimento, os membros preexistentes da comunidade internacional limitam-se a comprovar/atestar (ou a declarar) tal facto, não outorgando qualquer qualidade ou estatuto jurídico ao sujeito recém-formado ${ }^{54}$.

Deste modo, a falta de reconhecimento, por si só, não contende com a existência de um Estado. Inversamente, um acto de reconhecimento de nada valerá na ausência dos sobreditos elementos constitutivos ${ }^{55}$. Daqui não se conclua, porém, reconduzir-se o reconhecimento a um mero e inócuo formalismo, pois que tal conclusão seria precipitada. Secundando Fauchille, que impetrou o benefício da analogia com o Direito civil, poderá dizer-se que antes do reconhecimento o Estado possui capacidade de gozo, mas não capacidade de exercício dos seus direitos de soberania. O que, portanto, significa diferir sobremaneira a situação jurídica do novo membro da comunidade internacional antes e depois do reconhecimento pelos seus pares. De tal forma que, até que este sobrevenha, o Estado se encontra numa espécie de limbo ou de semi-soberania.

Só assim, de resto, se explica o afã das múltiplas iniciativas político-diplomáticas em se desdobram os representantes dos Estados recém-formados, com o intuito de obterem o reconhecimento pelo maior número possível de Estados e organizações internacionais.

Na verdade, se, internamente - tal como se preceitua na Carta da Organização dos Estados Americanos (art. 13. ${ }^{\circ}$ ), na sequência das alterações que lhe foram introduzidas pelo Protocolo de Buenos Aires, de 1992 - pode o Estado não reconhecido, de forma plena e exclusiva (com o limite dos direitos dos demais Estados), defender as respectivas integridade e independência, assegurar a sua

$54 \mathrm{O}$ valor meramente declarativo do reconhecimento encontra-se, de resto, expressamente consagrado na Carta da Organização dos Estados Americanos (art. 12..$^{\circ}$ respectivo), na senda, aliás, do que sempre fora o entendimento do Instituto de Direito Internacional.

55 De notar, todavia, que o direito internacional admite o reconhecimento prematuro de entidades que, não reunindo ainda os atributos necessários à existência de um Estado, virão, previsivelmente, a alcançá-los num prazo mais ou menos alargado (v.g., o reconhecimento de insurrectos e beligerantes). Tal reconhecimento assume, no entanto, uma natureza e um valor jurídico distintos do do Estado. Cfr. inter alia, GONÇALVES PEREIRA/FAUSTO DE QUADROS, Manual..., cit., pp. 317 e ss. 
conservação e a sua prosperidade e, portanto, organizar-se como melhor lhe aprouver, designadamente legislando, administrando e definindo a jurisdição e competência dos seus tribunais, no plano internacional é notoriamente mais limitada a sua liberdade de acção. De facto, não podendo compelir os outros Estados a considerarem oponíveis nos seus territórios os actos jurídicos por si praticados, o Estado que não haja sido objecto de reconhecimento, vê, em muito, reduzido o alcance extraterritorial da sua legislação e das sentenças dos seus tribunais. Por outro lado, a falta de reconhecimento, não obstando, embora, a que, se modo fragmentário, sejam encetados contactos não oficiais com terceiros v.g., missões oficiosas, relações comerciais ou, até consulares, acordos de escassa amplitude, etc. (Salmon; Díez de Velasco) — impede, contudo, inevitavelmente, o entabulamento oficial de relações diplomáticas solenes, através de embaixadas, com aqueles que tenham recusado outorgar o reconhecimento ${ }^{56}$.

Contornos diversos do reconhecimento do Estado, assume o problema do reconhecimento de governos. Até porque pode reconhecer-se um Estado, mas não o seu governo ${ }^{57}$. Como se sabe, são tradicionalmente, duas as correntes ou directrizes acerca do reconhecimento de governos: a doutrina da legitimidade (ou de Tobar) e a doutrina da efectividade (ou de Estrada). Se a primeira claramente se avantaja em termos de justiça material, certo é que os ditames da Realpilitik, coligados com a influência irradiante (ainda hoje) do princípio da efectividade, têm conduzido, na prática internacional, a uma clara preponderância da segunda. Eis senão quando, a recente crise vivida na Venezuela parece, de alguma sorte, ter deixado tranparecer um tímido recobramento da tese da legitimidade democrática e, até, em termos mais gerais, de um pretenso "direito à democracia", no quadro do direito de autodeterminação interna. Efectivamente, parte substancial dos Estados e organizações

56 Cfr. QUOC DINH/DAILLIER/PELLET, Droit International... cit., pp. 532-534; e o nosso Direito Internacional..., cit., p. 260. Bem demonstrativa dessa soberania limitada é a situação do Kosovo, a respeito de cujo reconhecimento, a partir da declaração unilateral de independência desse território, a comunidade internacional praticamente se dividiu a meio. Divisão essa também evidente no seio do próprio Conselho de Segurança das Nações Unidas.

57 Note-se que em causa estão, evidentemente, as autoridades políticas que, num determinado Estado, ascendem ao poder fora da regularidade ou ao arrepio dos procedimentos jurídico-constitucionais normais (v.g, por via revolucionária ou na sequência de fortes convulsões políticas internas) e se arvoram em representantes legítimos desse Estado. Já uma substituição de governos de harmonia com as formas constitucionais, não deve suscitar, sob pena de inaceitável ingerência nos assuntos internos do Estado, qualquer tomada de posição negativa por banda de terceiros. 
internacionais não reconheceu os resultados dos diversos processos eleitorais ocorridos naquele país, em particular a reeleição de Nicolás Maduro, em 2018. Muitos países interromperam relações diplomáticos com a Venezuela e alguns chegaram mesmo a nomear embaixadores junto de Juan Guaidó, Presidente da Assembleia Nacional, que viria, em Janeiro de 2019, a autoproclamar-se Presidente da Venezuela. Na sua Declaração de 10 de Janeiro de 2019, em nome da União Europeia, sobre o novo mandato do Presidente Maduro, a Alta Representante chagaria mesmo a afirmar que as eleições realizadas na Venezuela no pretérito mês de Maio não haviam sido livres nem justas, pelo que o seu resultado não tinha qualquer credibilidade, apelando à marcação de novas eleições presidenciais, em conformidade com as normas democráticas internacionalmente reconhecidas e com a ordem jurídico-constitucional interna. Apesar disso, importa relevar que, em rigor, nunca foi reconhecido um governo de Juan Guaidó, nos termos do direito internacional. Guaidó foi reconhecido, isso sim (nomeadamente pelo Governo português), como Presidente interino com legitimidade para convocar e organizar eleições presidenciais livres e conformes às práticas democráticas internacionalmente aceites, de harmonia com o previsto na Constituição venezuelana. A subtileza não é de somenos, evidenciando, juntamente com as vicissitudes políticas e diplomáticas que se seguiriam, as limitações da doutrina da legitimidade e convertendo o alvitre do propalado "direito à democracia" numa espécie de wishful thinking de alguns. 
